\author{
WITOLD MAŁECKI \\ Uniwersytet Wrocławski \\ e-mail: witold.malecki@uwr.edu.pl
}

\title{
Sprawozdanie z Międzynarodowej Konferencji Naukowej „Prawo i administracja wobec współczesnych problemów społecznych, gospodarczych i międzynarodowych", Wrocław, 9-10 czerwca 2017 r.
}

Postępujące współcześnie zjawiska społeczne i gospodarcze — globalizacja, integracja gospodarcza, konwergencja społeczna i kulturowa, cyfryzacja oraz wiele innych - nie mogą pozostawać bez odzwierciedlenia w treści regulacji prawnych, winnych efektywnie spełniać zadanie dostosowywania normatywnych ram funkcjonowania władzy publicznej i społeczeństwa do zmieniającej się nieustannie i w wielu sferach — rzeczywistości. Wobec zjawiska globalizacji współczesne problemy i wyzwania przybierają nader często zasięg ponadkrajowy, kształtując się zarówno w skali międzynarodowej, jak i lokalnej, gdzie tożsamość autonomicznych problemów poszczególnych państw i regionów wynika ze zbliżonych i wciąż upodabniających się kontekstów społecznych i gospodarczych.

Według Francisa Fukuyamy ,nie da się zatrzymać globalizacji, ale możemy sterować nią tak, by była jak najbardziej korzystna dla społeczeństwa"1 — zadanie sterowania przypada zaś władzy publicznej, która w państwie praworządnym może realizować je za pomocą instrumentów normatywnych.

$\mathrm{Z}$ uwagi na powyższe refleksja nauki prawa nad środkami reakcji władzy publicznej wobec problemów i wyzwań współczesności, kształtująca się z natury rzeczy na gruncie poszczególnych ustawodawstw krajowych, wydaje się warta

${ }^{1}$ Zob. F. Fukuyama, Nowy, potworny świat, „Trybuna” 15.03.2004. 
dopełnienia wiadomościami o sposobach oddziaływania na zbliżone i tożsame problemy w zagranicznych systemach prawnych.

Zarysowanemu celowi służyła organizacja na Wydziale Prawa, Administracji i Ekonomii Uniwersytetu Wrocławskiego Międzynarodowej Konferencji Naukowej „Prawo i administracja wobec współczesnych problemów społecznych, gospodarczych i międzynarodowych", która odbyła się w dniach 9-10 czerwca 2017 r. W konferencji wzięli udział prelegenci reprezentujący zarówno ośrodki polskie, jak i zagraniczne - w czasie konferencji 10 referatów zostało wygłoszonych przez przedstawicieli współpracujących z Uniwersytetem Wrocławskim uniwersytetów z Rosji (Wszechrosyjski Państwowy Uniwersytet Sprawiedliwości), Ukrainy (Lwowski Uniwersytet Narodowy im. Iwana Franko), Czech (Uniwersytet Masaryka w Brnie) i Chile (Uniwersytet Chilijski).

Wystąpienia zaprezentowane w pierwszym dniu konferencji zostały podzielone na trzy panele. Pierwszy z nich został poświęcony zagadnieniom działania administracji i prawa administracyjnego na tle ważkich współczesnych zjawisk i problemów. Analizowane w kontekście reakcji administracyjnoprawnej problemy koncentrowały się wokół zagadnień społecznych — funkcjonowania grup religijnych i rodziny (referaty prof. Galiny Kuleszowej i prof. Nadii Azisowej z Wszechrosyjskiego Państwowego Uniwersytetu Sprawiedliwości), problemów klimatycznych (referat dra Andrzeja Chajbowicza z Uniwersytetu Wrocławskiego) oraz materialnych i proceduralnych aspektów form działania administracji (referaty dra Lukáša Potěšila z Uniwersytetu Masaryka w Brnie oraz dra Andrzeja Pakuły i dra Macieja Błażewskiego z Uniwersytetu Wrocławskiego).

Wystąpienia podczas drugiego panelu pierwszego dnia konferencji skupiały się wokół zagadnień gospodarczych. Analizie poddawano zarówno kwestie prawnych aspektów handlu międzynarodowego (referaty Marii Gabrieli Vásquez Moncayo z Uniwersytetu Chilijskiego i mgr Agnieszki Grzelczak z Uniwersytetu Wrocławskiego), jak i sposobów oddziaływania ustawodawców krajowych na współczesne zjawiska gospodarcze w różnych porządkach prawnych (referaty prof. Wiktorii Małygi z Lwowskiego Uniwersytetu Narodowego im. Iwana Franko, dra Pavla Koukala z Uniwersytetu Masaryka w Brnie, dr Joanny Filaber z Wyższej Szkoły Prawa im. Heleny Chodkowskiej we Wrocławiu oraz dra Jarosława Odachowskiego z Wyższej Szkoły Bankowej w Opolu).

Trzeci panel pierwszego dnia konferencji został poświęcony zagadnieniom prawa międzynarodowego oraz ponadnarodowych kwestii współczesnej kultury prawnej. Doniosłe aktualnie problemy prawnomiędzynarodowe, związane z granicami działania prawa międzynarodowego i prawami człowieka, poruszyli prof. Wasyl Repecki (Lwowski Uniwersytet Narodowy im. Iwana Franko) i Jelena Nemowa (Wszechrosyjski Państwowy Uniwersytet Sprawiedliwości). Wprost do sygnalizowanej na wstępie niniejszego opracowania problematyki globalizacji odnosił się referat dra Mateusza Szymury (Uniwersytet Wrocławski), dotyczący harmonizacji prawa prywatnego w erze globalizacji. Zagadnienia związane z pro- 
blemami współczesnej kultury prawnej w kontekście krajowym i międzynarodowym przedstawiły Elizawieta Mercałowa i Aliona Czapłygina (Wszechrosyjski Państwowy Uniwersytet Sprawiedliwości) oraz mgr Elżbieta Kocowska-Siekierka (Uniwersytet Wrocławski).

Podczas drugiego dnia konferencji wygłoszone zostały referaty przygotowane przez doktorantów i studentów Wydziału Prawa, Administracji i Ekonomii Uniwersytetu Wrocławskiego. Wystąpienia dotyczyły przede wszystkim zagadnień administracyjnoprawnych. Poruszone zostały m.in. niezwykle istotne współcześnie problemy informatyzacji administracji i sądownictwa administracyjnego (referaty mgra Piotra Hica i mgr Bereniki Czerwińskiej), administracyjnoprawnych aspektów organizacji zgromadzeń (referat mgra Jakuba Zabłockiego), pozycji prawnej uchodźców (referat Darii Bańkowskiej) oraz planowanej reformy publicznoprawnego statusu przedsiębiorców (referat mgra Artura Łysonia).

Organizacja konferencji niewątpliwie przyczyniła się do poszerzenia perspektyw uczestniczących w niej badaczy nauki prawa o zagraniczne doświadczenia z zakresu prawnych instrumentów oddziaływania na współczesne problemy i wyzwania, prowadząc i inspirując do refleksji natury komparatystycznej.

Konferencja przyczyniła się również do pogłębienia współpracy Wydziału Prawa, Administracji i Ekonomii Uniwersytetu Wrocławskiego z ośrodkami zagranicznymi, rozszerzając perspektywy jej rozwoju poprzez organizację podobnych, sprzyjających refleksji naukowej przedsięwzięć w przyszłości — zarówno we Wrocławiu, jak i za granicą. 